\title{
Evaluation of anxiety levels of pregnant women with gestational diabetes mellitus
}

\author{
Aşkın Evren Güler ${ }^{1}$ (D) , Zeliha Çiğdem Demirel Güler ${ }^{1}$ (D) , Asil Budak ${ }^{2}$ (D), \\ Buket Koparal' ${ }^{3}$ iD, Özge Şehirli Kıncı ${ }^{4}$ \\ ${ }^{1}$ Department of Obstetrics and Gynecology, Private Koru Ankara Hospital, Ankara, Turkey \\ ${ }^{2}$ Department of Psychiatry, Medical Park Göztepe Hospital, Istanbul, Turkey \\ ${ }^{3}$ Department of Psychiatry, Training and Research Hospital, Recep Tayyip Erdoğan University, Rize, Turkey \\ ${ }^{4}$ Department of Obstetrics and Gynecology, Training and Research Hospital, Mŭğla Sıtkı Koçman University, Muğla, Turkey
}

\begin{abstract}
Objective: The aim of this study was to investigate the anxiety levels of pregnant women with gestational diabetes mellitus (GDM) followed by different treatment methods.

Methods: Our study was carried out with 141 cases whose pregnancy follow ups were made in Gynecology and Obstetrics Clinic. Cases which had GDM screening with 75-g oral glucose tolerance test (OGTT) were divided into 3 groups. Group 1 (control group) consisted of 50 cases with 75 -g OGTT results in normal range, Group 2 consisted of 50 cases which had significant 75-g OGTT results and followed up by diet (A1), and Group 3 consisted of 41 cases which were diagnosed with GDM as a result of 75-g OGTT and received diet as well as medical therapy (A2). Beck anxiety inventory (BAI) was administered to the patients in Group 1 in 24th week, and to patients in Groups 2 and 3 in the 24th and 32nd weeks.

Results: In the first evaluation of the patients, BAI scores of the control group were statistically found to be significantly lower than the patients with GDM ( $\mathrm{p}=0.001)$. There was no significant difference in BAI scores among patients diagnosed with GDM, and high anxiety scores were found in both groups. There was a significant decrease in anxiety levels in the Groups 2 and 3 after the treatment ( $<<0.01)$. In the Group 2, the BAI scores were observed to decrease from $51.76 \pm 4.47$ to $45.62 \pm 3.65$, and from $51.73 \pm 5.27$ to $41.48 \pm 3.29$ in the Group 3 ( $\mathrm{p}<0.001)$.

Conclusion: In addition to the metabolic disorders brought by the disease itself, GDM can cause various problems by increasing the levels of anxiety in patients. With an effective treatment for glycemic control, anxiety levels of patients can be reduced.
\end{abstract}

Keywords: Anxiety, gestational diabetes mellitus, Beck anxiety inventory.

\section{Özet: Gestasyonel diabetes mellituslu gebelerde anksiyete seviyelerinin değerlendirilmesi}

Amaç: Bu çalışmanın amacı, farklı tedavi yöntemleri sonrasında gestasyonel diabetes mellituslu (GDM) gebelerde anksiyete seviyelerini araştırmaktı.

Yöntem: Çalışmamız, Kadın Hastalıkları ve Doğum Kliniğinde gebelik takipleri yapılan 141 olgu ile gerçekleştirildi. 75 g oral glikoz tolerans testi (OGTT) ile GDM taraması yapılan olgular 3 gruba ayrıldı. Grup 1 (kontrol grubu) $75 \mathrm{~g}$ OGTT bulguları normal aralık içinde olan 50 olgudan, Grup 2 anlamlı 75 g OGTT bulguları olan ve diyet uygulayan 50 olgudan (A1) ve Grup 3 ise 75 g OGTT sonucunda GDM tanisı alan ve tıbbi tedavinin yanı sıra diyet uygulanan 41 olgudan (A2) oluşmaktaydı. Beck anksiyete ölçeği (BAÖ) Grup 1'deki olgulara 24. haftada, Grup 2 ve 3 'teki olgulara ise sırasıyla 24. ve 32 . haftalarda uygulandı.

Bulgular: Hastaların ilk değerlendirmesinde, kontrol grubunun BAÖ puanları istatistiksel olarak anlamlı şekilde GDM'li olgulardan daha düşük bulundu $(\mathrm{p}=0.001)$. GDM tanısı alan hastalar arasında BAÖ puanları yönünden anlamlı bir fark yoktu ve her iki grupta yüksek anksiyete puanları bulundu. Tedavi sonrasında Grup 2 ve 3 'te anksiyete seviyelerinde anlamlı bir düşüş gözlemlendi $(\mathrm{p}<0.01)$. Grup 2 ve Grup 3'te BAÖ puanlarının sirasiyla 51.76 \pm 4.47 'den $45.62 \pm 3.65$ 'e ve $51.73 \pm 5.27$ 'den $41.48 \pm 3.29$ 'a düştüğü gözlemlendi $(\mathrm{p}<0.001)$.

Sonuç: Hastalığın kendisinin sebep olduğu metabolik bozukluklara ek olarak GDM, hastalarda anksiyete seviyelerini artırarak çeşitli sorunlara yol açabilir. Glisemik kontrol için etkili bir tedavi ile hastaların anksiyete seviyeleri azaltılabilir.

Anahtar sözcükler: Anksiyete, gestasyonel diabetes mellitus, Beck anksiyete ölçeği.

Correspondence: Özge Şehirli Kınc1, MD. Department of Obstetrics and Gynecology, Training and Research Hospital, Muğla Sıtkı Koçman University, Muğla, Turkey. e-mail: drozgesehirlikinci@gmail.com / Received: March 16, 2020; Accepted: June 9, 2020

Please cite this article as: Güler AE, Demirel Güler ZÇ, Budak A, Koparal B, Şehirli Kıncı Ö. Evaluation of anxiety levels of pregnant women with gestational diabetes mellitus. Perinatal Journal 2020;28(2):89-94. doi:10.2399/prn.20.0282010 


\section{Introduction}

Gestational diabetes mellitus (GDM) is one of the most important metabolic diseases of pregnancy. ${ }^{[1]}$ The incidence of GDM in our country varies between $6.9-8.9 \% .{ }^{[2]}$ GDM is very important because it has negative effects on the fetus as well as negative maternal effects and may also cause complications in postpartum period. ${ }^{[3]}$ In this period, depression and anxiety disorders can be triggered due to the medical problems caused by the disease as well as the increasing anxiety of the mother about her baby. ${ }^{[4]}$

Along with changes in social relationships and roles within the family, pregnancy also leads to changes in body image. ${ }^{[2]}$ In addition to hormonal changes, changes of roles in social life also cause anxiety in pregnancy and other procedures in gynecology. ${ }^{[5-7]}$ Unhappiness, pessimism, fatigue, malaise and sleep disorders experienced by pregnant individuals are generally seen as the nature of pregnancy, and can often be overlooked. ${ }^{[8-10]}$ In studies performed, it has been reported that antenatal depression rates are between $9.9-45 \%$ and anxiety rates are around $6.6-75 \%{ }^{[11,12]}$ There are many studies showing that anxiety and depression lead to complications such as premature birth, low birth weight, and nutrition disorders during pregnancy. ${ }^{[1,14]}$

In our study, we aimed to examine the anxiety states of pregnant women who had GDM and were managed with different treatment methods.

\section{Methods}

Our study was carried out with 141 cases whose pregnancy follow ups were made in Gynecology and Obstetrics Clinic. Ethical approval for the study was obtained from the Ethics Committee, Koru Ankara Hospital (Ethics Committee protocol code: 13/11/2018-17). GDM screening was performed in one step with 75-g OGTT. For 75-g OGTT, it was based on recommendation values (pre-prandial blood glucose: $92 \mathrm{mg} / \mathrm{dl}$, postprandial 1st hour: $180 \mathrm{mg} / \mathrm{dl}$, postprandial 2nd hour: $153 \mathrm{mg} / \mathrm{dl}$ ) of the International Association of Diabetes and Pregnancy Study Groups (IADPSG). A single high value was considered diagnostic for GDM ${ }^{[15]}$ All cases were divided into 3 groups. Group 1 (control group) with 75g OGTT results in normal range consisted of 50 cases. Group 2 also consisted of 50 cases which had significant 75-g OGTT results, namely diagnosed as GDM, and followed up by diet without any medical treatment (A1).
Group 3 consisted of 41 cases which were diagnosed with GDM as a result of 75-g OGTT and received diet as well as medical therapy (insulin treatment) (A2). All patients with GDM were followed up with a multidisciplinary approach by consulting the Endocrine and Metabolic Diseases and Psychiatry Polyclinics.

\section{Data collection tools}

The patient polyclinic anamnesis information screen where socio-demographic data was recorded was used as the primary measurement instrument. Age, gravida and parity numbers, educational status, employment status and body mass index (BMI) of the patients were recorded in the socio-demographic data form. Beck anxiety inventory was used as a secondary measurement instrument. These forms were filled out during antenatal pregnancy follow-up in the specified week.

Beck anxiety inventory (BAI), which was developed by Beck et al. in 1988, is being used to determine the frequency of anxiety symptoms. ${ }^{[16]}$ The scale is composed of 21 items, it is four Likert type and each item is evaluated with a score of $0-3$. The Turkish validity and reliability study of the scale was conducted by Ulusoy et al. in 1998. ${ }^{[17]}$ The highest score obtainable in the scale is 63 . Being high of the overall score indicates a high level of anxiety or severity.

\section{Application of research}

The 1st questionnaire study for all 3 groups was performed on a pregnancy visit immediately after the $75-\mathrm{g}$ OGTT was concluded. No recurrent questionnaire evaluation was performed for the Group 1 . The patients with GDM in the Groups 2 and 3 were also evaluated by the psychiatrist and taken under follow-up. The 2nd questionnaires applied for all pregnant women in the Groups 2 and 3, whose follow-up and treatment regimens were planned by the endocrine and metabolic diseases specialist, were performed about at 8 th week (about 32nd week of gestation) following the GDM diagnosis. In all the cases with GDM in the Groups 2 and 3 included in the study, glycemic follow-ups were normal and no additional fetal or maternal problems were observed during application of the 2 nd questionnaire.

\section{Inclusion and exclusion criteria in research}

Patients who were diagnosed with GDM as a result of OGTT and had no exclusion criteria were included in the study. Patients in low risk group (being of normal 
weight before pregnancy, age $<25$, no known DM in first degree relatives, nonexistence of bad obstetric history) and without OGTT, who had a psychiatric disease history in their anamnesis, who had other stressors such as fetal (oligohydramnios, polyhydramnios, growth retardation, macrosomia, affected rh incompatibility, etc.) or maternal (myoma, premature birth history, smoking, history of late abortion or fetal loss, recurrent pregnancy loss history, blood pressure, pregestational $\mathrm{DM}$, etc.) which could cause anxiety during pregnancy follow-ups were excluded from the study.

\section{Statistical analysis}

All statistical analyses were performed using the SPSS ver. 25.0 (SPSS Inc., Chicago, IL, USA). The data were evaluated by the Kolmogorov-Smirnov test for normal distribution. It was observed that none of the data groups except age was distributed normally. Because there were more than two independent groups and they did not fit the normal distribution, the difference between the groups was investigated by Kruskal-Wallis H test. Oneway ANOVA test was used to evaluate the age group since it distributed normally. In cases where the difference was significant, pair wise comparisons after Bonferroni correction for multiple tests were obtained. Wilcoxon test was used to compare anxiety scores at 24th and 32nd weeks. Descriptive statistics were used to calculate the frequency, mean, median, mode and dispersion (range, variance, $\mathrm{SD}$, maximum, minimum) for each variable when appropriate. Mann-Whitney $U$ test was used to evaluate the BAI results between the groups. A $\mathrm{p}<0.05$ value was accepted as significant statistically.

\section{Results}

Of the 141 patients included in the study, 50 were women diagnosed without GDM and 91 with GDM. The sociodemographic data of the patients was shown in Table 1. Comparing maternal age-pregnancy and birth number, body mass indexes and educational status, there was no statistically significant difference between the groups ( $>0.05)$.

In the first evaluation of the patients, BAI scores in the control group (Group 1) were found to be significantly lower than those of patients with GDM (KruskalWallis test $\mathrm{p}<0.001)$. This difference was observed to be between the Groups 1 and 2 (MWU test $\mathrm{p}=0.001$ ) and between the Groups 2 and 3 (MWU test $\mathrm{p}=0.001$ ). There was no significant difference in BAI scores among patients diagnosed with GDM (Group 2 and Group 3), and high anxiety scores were found in both groups (MWU test $\mathrm{p}=0.997$ ). The group with the diagnosis of GDM, the group whose blood glucose was regulated by diet (Group 2), and also the group with insulin regula-

Table 1. Demographic characteristics of the groups.

\begin{tabular}{|c|c|c|c|c|}
\hline & $\begin{array}{l}\text { Control group } \\
\qquad(n=50)\end{array}$ & $\begin{array}{l}\text { GDM A1 } \\
(n=50)\end{array}$ & $\begin{array}{c}\text { GDM A2 } \\
(n=41)\end{array}$ & p-value \\
\hline Age (mean \pm SD deviation) & $28.12 \pm 2.23$ & $27.49 \pm 1.81$ & $29.42 \pm 2.48$ & $0.612^{*}$ \\
\hline Gravida (median, min-max) & $2(2-3)$ & $2(2-3)$ & $2(2-3)$ & $1^{\dagger}$ \\
\hline Parity (median, min-max) & $1(1-1)$ & $1(1-1)$ & $1(1-1)$ & $1^{\dagger}$ \\
\hline BMI (mean \pm SD deviation) & $22.13 \pm 4.21$ & $24.02 \pm 3.18$ & $21.82 \pm 4.88$ & $0.128^{+}$ \\
\hline OGTT week (mean \pm SD deviation) & $24.2 \pm 0.14$ & $24.28 \pm 0.24$ & $25.01 \pm 0.44$ & $0.112^{+}$ \\
\hline \multicolumn{5}{|c|}{ Employment status of the mother in pregnancy $\mathrm{n}(\%)$} \\
\hline Working & $41(82 \%)$ & $40(80 \%)$ & $33(80 \%)$ & $0.064^{+}$ \\
\hline Not working & $9(18 \%)$ & $10(20 \%)$ & $8(20 \%)$ & $0.347^{+}$ \\
\hline \multicolumn{5}{|l|}{ Educational status } \\
\hline Primary school n (\%) & $3(6 \%)$ & $4(8 \%)$ & $3(7.3 \%)$ & $0.268^{+}$ \\
\hline Middle school n (\%) & $2(4 \%)$ & $2(4 \%)$ & $2(4.9 \%)$ & $1^{\dagger}$ \\
\hline High school n (\%) & $10(20 \%)$ & $10(20 \%)$ & $8(19.5 \%)$ & $0.174^{+}$ \\
\hline University n (\%) & $35(70 \%)$ & $34(70 \%)$ & $28(68.3 \%)$ & $0.084^{+}$ \\
\hline Week of the first survey & $24.28 \pm 0.53$ & $24.32 \pm 0.68$ & $24.27 \pm 0.88$ & $0.815^{+}$ \\
\hline Week of the second survey & - & $32.12 \pm 0.62$ & $32.92 \pm 0.36$ & $0.782^{+}$ \\
\hline
\end{tabular}

SD: standard deviation. ${ }^{*}$ One-way test; ${ }^{\dagger}$ Kruskal-Wallis test. 
tion (Group 3) showed a significant decrease in anxiety levels after treatment. Comparing the 24th and 32nd weeks, it was seen that BAI scores in the group followed by the diet (Group 2) were decreased from 51.76 4.47 to $45.62 \pm 3.65$; in the group followed by diet and insulin treatment (Group 3) from $51.43 \pm 5.29$ to $41.48 \pm 3.29$, and that the difference was statistically significant (Wilcoxon test $\mathrm{p}=0.001$ ). Details of anxiety levels of patients are shown in Table 2.

\section{Discussion}

GDM is a situation which is increasing in frequency all over the world and has a significant effect on maternal and fetal health. ${ }^{[18]}$ In addition to GDM, situations such as treatment originated problems, possible complications, future anxiety, anxiety of being dependent on others may cause problems on the cognitive and social life of pregnant women. ${ }^{[19]}$ In addition to the concerns about the fetus in pregnant individuals, the increase of concerns about the development of the fetus and possible problems may have led to an increase in the anxiety levels of patients. ${ }^{[20]}$ This explains the difference in anxiety levels between mothers with GDM and without GDM. The aim of this study was to investigate the anxiety levels of pregnant women diagnosed with GDM and to evaluate the effect of treatment method on anxiety levels.

In our study, when the socio-demographic data of the pregnant women who were diagnosed with GDM were compared to individuals without GDM, it was observed that there was no statistically significant difference between two groups. In the study of Lao et al., increased maternal age is reported to be a risk factor for GDM. ${ }^{[2]}$ While the prevalence of GDM is reported to be between $0.4-0.8 \%$ in individuals below 25 years of age, this rate is reported as $4.3-5.5 \%$ in the group above 25 years of age. ${ }^{[21]}$ All the pregnant women included in our study were found to be in the group with risk of GDM due to age.
In many studies performed, it was reported that GDM may cause antenatal depression and anxiety. ${ }^{[9,20,22-25]}$ In the study of Daniells et al., although anxiety and depression levels were found to be high in individuals with GDM at the time of diagnosis, it was reported that this difference lost its significance in follow-ups and that there was no difference in anxiety levels between those with GDM and without GDM. ${ }^{[20]}$ Also in our study, anxiety levels of patients in Group 2 and Group 3 decreased with time. However, the control group (Group 1) did not have the anxiety scale again. This is a restriction of our study. In a study by Ferrari et al., it was found that $13 \%$ of patients with GDM had moderate-severe depressive symptoms, and that body mass index, blood pressure and visceral fat volume were higher in this group. ${ }^{[2]}$ In a study performed by Orbay et al. in our country with 281 pregnant women, anxiety scores were reported to be higher in individuals with GDM. ${ }^{[26]}$ However, in this study, Hospital anxiety and depression (HAD) scale was used, and patients diagnosed with GDM were not divided into groups. In our study, the exclusion of individuals with known psychiatric diseases from the study provided the identification of mild-moderate anxiety symptoms in patients with the help of a scale based on their own reports.

The pregnancy itself is a period in which the mother experienced many physical and mental changes and may have been very anxious for both herself and her baby. ${ }^{[27]}$ In the study performed by Felice et al., the incidence of psychiatric disorders in pregnancy was found to be about $19.2 \%$, and $14.8 \%$ of this were found to be the pregnancy anxiety and depression. ${ }^{[28]}$ The pregnancy anxiety and depression were associated with low birth weight, premature birth and infant nutrition problems. ${ }^{[7,29]}$ In our study, patients with high anxiety scores were followed up multidisciplinary in the antenatal period, but the postnatal results were not evaluated. This is another restriction of our study.

Table 2. Evaluation of anxiety levels of the groups.

\begin{tabular}{lcccc} 
& $\begin{array}{c}\text { Control group } \\
(\mathbf{n}=\mathbf{5 0 )}\end{array}$ & $\begin{array}{c}\text { GDM A1 } \\
(\mathbf{n}=\mathbf{5 0})\end{array}$ & $\begin{array}{c}\text { GDM A2 } \\
(\mathbf{n}=\mathbf{4 1 )}\end{array}$ & $\begin{array}{c}\text { p-value } \\
24 \text { weeks }\end{array}$ \\
\hline 3 weeks & $38.72 \pm 4.76$ & $51.76 \pm 4.47$ & $51.73 \pm 5.27$ & $0.001^{*}$ \\
\hline
\end{tabular}

*One-way test; †Kruskal-Wallis test. 
In our study, a multidisciplinary treatment approach was applied to mothers diagnosed with GDM by having been directed to endocrine and metabolic diseases and psychiatry polyclinics. The patients were informed about diabetes and some of them were followed up with only diet and some others with diet+insulin treatment. The patients were evaluated by psychiatrist and followed up with psychoeducation as well as supportive interviews. In spite of the high anxiety scores of the patients, having had no significant deterioration in their functionalities allowed them to be followed up without medical treatment. It was found that there was a significant decrease in anxiety levels because of improvement provided in blood glucose levels in the process (Table 2, $\mathrm{p}<0.01$ ). Regardless of the treatment method, besides providing the blood glucose regulation of the patients, psychoeducation and supportive interviews are thought to contribute to the decrease in anxiety levels of patients. In a study investigating stress coping methods in pregnant women with GDM, it was found that HbA1c levels were lower in those who exhibited more optimistic and modest approach against stress. ${ }^{[2]}$ Increasing the coping mechanisms of patients can lead them to better deal with diabetes and related problems as well as pregnancyrelated problems in general. However, in a recent study in which the effects of educational videos in women with GDM on anxiety and glycemic control were examined, no difference was found between the groups. ${ }^{[30]}$

\section{Conclusion}

In this study, we only evaluated anxiety levels of the patients. A measurement method was not used to assess depressive symptoms. The relationship between the clinical variables and the anxiety levels of the patients was not examined, and this is among the important restrictions. In this area, prospective studies with longer follow-up of patients are needed.

Conflicts of Interest: No conflicts declared.

\section{References}

1. Guariguata L, Linnenkamp U, Beagley J, Whiting DR, Cho NH. Global estimates of the prevalence of hyperglycaemia in pregnancy. Diabetes Res Clin Pract 2014;103:176-85. [PubMed] [CrossRef]

2. Surucu HA, Besen DB, Duman M, Yeter Erbil E. Coping with stress among pregnant women with gestational diabetes mellitus. J Caring Sci 2018;7:9-15. [PubMed] [CrossRef]
3. Mitanchez D. Foetal and neonatal complications in gestational diabetes: perinatal mortality, congenital malformations, macrosomia, shoulder dystocia, birth injuries, neonatal complications. Diabetes Metab 2010;36:617-27. [PubMed] [CrossRef]

4. Trutnovsky G, Panzitt T, Magnet E, Stern C, Lang U, Dorfer M. Gestational diabetes: women's concerns, mood state, quality of life and treatment satisfaction. J Matern Fetal Neonatal Med 2012;25:2464-6. [PubMed] [CrossRef]

5. Ross LE, McLean LM. Anxiety disorders during pregnancy and the postpartum period: a systematic review. J Clin Psychiatry 2006;67:1285-98. [PubMed] [CrossRef]

6. Kinci MF, Yesilcinar I, Acavut G, Kinci OS, Karasahin KE. The opinions and thoughts of the women who had undergone hysterosalpingography for the first time: a qualitative study. International Journal of Caring Sciences 2020;13:683-91.

7. Lopez LM, Bernholc A, Zeng Y, Allen RH, Bartz D, O’Brien $\mathrm{PA}$, et al. Interventions for pain with intrauterine device insertion. Cochrane Database Syst Rev 2015;(7):CD007373. [PubMed] [CrossRef]

8. Kaya Zaman F, Özkan N, Toprak D. Gebelikte depresyon ve anksiyete. Konuralp Tip Dergisi 2018;10:20-5. [CrossRef]

9. Yeşilcinar I, Yavan T, Karasahin KE, Yenen MC. The identification of the relationship between the perceived social support, fatigue levels and maternal attachment during the postpartum period. J Matern Fetal Neonatal Med 2017;30:121320. [PubMed] [CrossRef]

10. Demirel Guler ZC, Guler AE, Kıncı MF, Aktürk E. Does parity and labor influence anxiety levels of pregnant women? Perinatal Journal 2019;27:43-8. [CrossRef]

11. Eskici L DrA, Atasoy N, Arıkan İ, Harma M. Gebelerde depresyon ve anksiyete bozukluğunun obstetrik sonuçları ve yenidoğan üzerine etkileri. Anatolian Journal of Clinical Investigation 2012;6:10-6.

12. Vesga-Lopez O, Blanco C, Keyes K, Olfson M, Grant BF, Hasin DS. Psychiatric disorders in pregnant and postpartum women in the United States. Arch Gen Psychiatry 2008;65: 805-15. [PubMed] [CrossRef]

13. Wadhwa PD, Sandman CA, Porto M, Dunkel-Schetter C, Garite TJ. The association between prenatal stress and infant birth weight and gestational age at birth: a prospective investigation. Am J Obstet Gynecol 1993;169:858-65. [PubMed] [CrossRef]

14. McMahon, MJ, Ananth CV, Liston RM. Gestational diabetes mellitus. Risk factors, obstetric complications and infant outcomes. J Reprod Med 1998;43:372-8. [PubMed]

15. International Association of Diabetes and Pregnancy Study Groups Consensus Panel; Metzger BE, Gabbe SG, Persson B, Buchanan TA, Catalano PA, Damm P, et al. International association of diabetes and pregnancy study groups recommendations on the diagnosis and classification of hyperglycemia in pregnancy. Diabetes Care 2010;33:676-82. [PubMed] [CrossRef]

16. Beck AT, Epstein N, Brown G, Steer RA. An inventory for measuring clinical anxiety: psychometric properties. J Consult Clin Psychol 1988;56:893-7. [PubMed] [CrossRef]

17. Ulusoy M, Sahin N, Erkmen H. Turkish version of Beck Anxiety inventory: psychometric properties. Journal of Cognitive Psychotherapy 1998;12:163-72. 
18. Dabelea D, Snell-Bergeon JK, Hartsfield CL, Bischoff KJ, Hamman RF, McDuffie RS, et al. Increasing prevalence of gestational diabetes mellitus (GDM) over time and by birth cohort: Kaiser Permanente of Colorado GDM Screening Program. Diabetes Care 2005;28:579-84. [PubMed] [CrossRef]

19. Byrn M, Penckofer S. The relationship between gestational diabetes and antenatal depression. J Obstet Gynecol Neonatal Nurs 2015;44:246-55. [PubMed] [CrossRef]

20. Daniells S, Grenyer BF, Davis WS, Coleman KJ, Burgess JA, Moses RG. Gestational diabetes mellitus: is a diagnosis associated with an increase in maternal anxiety and stress in the short and intermediate term? Diabetes Care 2003;26:385-9. [PubMed] [CrossRef]

21. Lao TT, Ho L-F, Chan BC, Leung W-C. Maternal age and prevalence of gestational diabetes mellitus. Diabetes Care 2006;29:948-9. [PubMed] [CrossRef]

22. Moyer VA, U.S. Preventive Services Task Force. Screening for gestational diabetes mellitus: U.S. Preventive Services Task Force recommendation statement. Ann Intern Med 2014;160: 414-20. [PubMed] [CrossRef]

23. Lawson EJ, Rajaram S. A transformed pregnancy: the psychosocial consequences of gestational diabetes. Sociology of Health and Illness 1994;16:536-62. [CrossRef]

24. Ferrari U, Banning F, Freibothe I, Tröndle K, Sacco V, Wichmann C, et al. Depressive symptoms, impaired glucose metabolism, high visceral fat, and high systolic blood pressure in a subgroup of women with recent gestational diabetes. J Psychiatr Res 2018;97:89-93. [PubMed] [CrossRef]

25. Hui AL, Sevenhuysen G, Harvey D, Salamon E. Stress and anxiety in women with gestational diabetes during dietary management. Diabetes Educ 2014;40:668-77. [PubMed] [CrossRef]

26. Orbay E, Tüzün S, Çınkıt B, Ölmez MB, Sinem Tekin EP, Bulut $S$, et al. Antenatal anxiety in pregnant women with gestational diabetes mellitus. Ankara Medical Journal 2017;17:18. [CrossRef]

27. Anniverno E, Bramante A, Mencacci C, Durbano F. Anxiety disorders in pregnancy and the postpartum period. In: Durbano F, editor. New insights into anxiety disorders. Rijeka: InTech; 2013. pp. 259-85.

28. Felice E, Saliba J, Grech V, Cox J, Calleja N. Antenatal psychiatric morbidity in Maltese women. Gen Hosp Psychiatry 2007;29:501-5. [PubMed] [CrossRef]

29. Muzik M, Marcus SM, Heringhausen JE, Flynn H. When depression complicates childbearing: guidelines for screening and treatment during antenatal and postpartum obstetric care. Obstet Gynecol Clin North Am 2009;36:771-88, ix-x. [PubMed] [CrossRef]

30. Draffin CR, Alderdice FA, McCance DR, Maresh M, Harper R, Patterson CC, et al. Impact of an educational DVD on anxiety and glycaemic control in women diagnosed with gestational diabetes mellitus (GDM): a randomised controlled trial. Diabetes Res Clin Pract 2017;126:164-71. [PubMed] [CrossRef]

Bu makalenin kullanım izni Creative Commons Attribution-NoCommercial-NoDerivs 3.0 Unported (CC BY-NC-ND3.0) lisansı aracılığıyla bedelsiz sunulmaktadır. / This work is licensed under the Creative Commons Attribution-NonCommercial-NoDerivs 3.0 Unported (CC BY-NC-ND3.0) License. To view a copy of this license, visit http://creativecommons.org/licenses/by-nc-nd/3.0/ or send a letter to Creative Commons, PO Box 1866 , Mountain View, CA 94042, USA. 